\title{
Sulfate Resistance of Rice Husk Ash Concrete
}

\author{
John Kamau ${ }^{1}$, Ash Ahmed $^{2 *}$, Killian Ngong ${ }^{3}$ \\ ${ }^{1}$ Naylor Concrete Products, Barnsley, S75 1HT, England, UK \\ ${ }^{2}$ Reader (Associate Professor), Civil Engineering Group, Leeds Beckett University, Leeds, UK \\ ${ }^{3}$ Senior Lecturer, Civil Engineering Group, Leeds Beckett University, Leeds, UK
}

\begin{abstract}
Durability of concrete is defined as its ability to resist deterioration after exposure to the environment of its use. This work investigates the performance of Rice Husk Ash (RHA) concrete in sodium sulfate $\left(\mathrm{Na}_{2} \mathrm{SO}_{4}\right)$, magnesium sulfate $\left(\mathrm{MgSO}_{4}\right)$ and combined $\mathrm{Na}_{2} \mathrm{SO}_{4}$ and $\mathrm{MgSO}_{4}$ solutions. Concrete bar specimens and cubes were prepared for expansion and strength deterioration tests respectively using RHA replacement at the $7.5 \%$ replacement by volume, which had achieved the highest compressive strength, as well as at the $30 \%$ replacement by volume, which was the highest replacement for the study. Strength deterioration tests were performed on the $7.5 \%$ replacement by the weight of cement. From the expansion test findings, it was concluded that at the $7.5 \%$ replacement, RHA could be used with an advantage over $100 \%$ cement concrete in $\mathrm{MgSO}_{4}$ environments, whereas at the $30 \%$ replacement, RHA could be used with an advantage over $100 \%$ cement concrete in both the $\mathrm{Na}_{2} \mathrm{SO}_{4}$ and mixed sulfate environments. RHA was also found to be more effective in resisting surface deterioration in all the sulfate solutions. The RHA specimens also exhibited superior strength deterioration resistance in comparison to the $100 \%$ cement specimens.
\end{abstract}

\section{Introduction}

Durability of concrete is defined as its ability to resist deterioration, thereby being capable of maintaining its original quality and form once it has been exposed to the environment of its use [1]. The deterioration of concrete can be caused by either internal chemical reactions from the constituents of concrete or external attacks from chemicals such as sulfates [1]. This study investigates sulfate attack, which is a major cause of the lack of durability in concrete.

It has been postulated by some that a possible result of sulfate attack on concrete is the loss of strength by affecting calcium hydroxide $\left[\mathrm{Ca}(\mathrm{OH})_{2}\right]$, a product of the hydration of cement, and the strength giving Calcium Silicate Hydrate (C-S-H), a product of the reaction between $\mathrm{Ca}(\mathrm{OH})_{2}$ and silicone dioxide $\left(\mathrm{SiO}_{2}\right)$ [2-9]. Gypsum and expansive ettringite are formed when Sodium sulfate $\left(\mathrm{Na}_{2} \mathrm{SO}_{4}\right)$ attacks $\mathrm{Ca}(\mathrm{OH})_{2}$ [2]. Ettringite, which grows as needle shaped crystals causes volume increases of up to $126 \%$ depending on exposure conditions, and can generate very high stresses, which if higher than the tensile strength of concrete can bring about cracking [2].

Decalcification of C-S-H in $\mathrm{Na}_{2} \mathrm{SO}_{4}$ attack to cause loss of strength is negligible, and for this reason, it has been suggested that $\mathrm{Na}_{2} \mathrm{SO}_{4}$ attack manifests and should be evaluated through expansion [2]. On the other hand, Magnesium sulfate $\left(\mathrm{MgSO}_{4}\right)$ attack has been reported to affect C-S-H, converting it to Magnesium Silicate Hydrate (M-S-H), which is not cementitious [2]; thus, a possible consequence of this, which has been suggested, is a loss of strength of concrete [2-9].

It has been posited that low sulfate resistance is caused by low levels of silicone dioxide $\left(\mathrm{SiO}_{2}\right)$, and high levels of sulfate $\left(\mathrm{SO}_{4}\right)$, iron $\left(\mathrm{Fe}_{2} \mathrm{SO}_{3}\right), \mathrm{Ca}(\mathrm{OH})_{2}$, and aluminate $\left(\mathrm{C}_{3} \mathrm{~A}\right)$ [3]. It has also been reported that a high molar ratio of sulfite $\left(\mathrm{SO}_{3}\right)$ to aluminium oxide $\left(\mathrm{Al}_{2} \mathrm{O}_{3}\right)$ enhances the formation of monosulfate, which leads to the formation of ettringite and gypsum on exposure to sulfate attack [2]. It has also been suggested that the reaction between Supplementary Cementitious Materials (SCMS) such as RHA and cement, which is also known as the pozzolanic reaction helps to dilute $\mathrm{C}_{3} \mathrm{~A}$ and remove $\mathrm{Ca}(\mathrm{OH})_{2}$ by converting it into $\mathrm{C}-\mathrm{S}-\mathrm{H}$, hence reducing the quantities of gypsum formed [2]. A poor performance of $\mathrm{SCMs}$ in $\mathrm{Mg}(\mathrm{SO})_{4}$ solutions has however been reported, since $\mathrm{Mg}(\mathrm{SO})_{4}$ mainly affects $\mathrm{C}$ $\mathrm{S}-\mathrm{H}$, which may result in the loss of strength [2-12].

Elsewhere, literature has it that permeability, which is defined as the rate at which pressured water can flow through interconnected voids within concrete, or the measure of how easily a liquid or gas can get through concrete, is the most important aspect of durability, since it slows down the flow of harmful substances into concrete [4], [5]. In as much as controlling the chemistry of concrete is vital as discussed above, it is more important to maintain low permeability [6,13-16]. SCMs reduce the permeability of concrete by the packaging

* Corresponding author: A.R.Ahmed@leedsbeckett.ac.uk 
effect of their unreacted particles, as well as by the help of the C-S-H that is formed as a result of their use, whose benefit is a less well interconnected capillary pore structure, that leads to lower permeability $[7,2,17,18]$.

It has further been suggested that the compressive strength of concrete is directly proportional to its durability, with low compressive strengths spelling low durability and vice versa [2-8]. This postulation is however, disputed by a number of concrete technologists. Nevertheless, it is vital to investigate any strength deterioration after prolonged exposure to a sulfate rich atmosphere.

RHA was defined by Bapat [2] as the product of incinerated rice husk, which is the outer shell that covers the rice kernel, the product of threshed paddy to separate rice grain and the husk. Its suitability as a SCM was investigated by the authors of this paper [9], who evaluated the strength of concrete using untreated rice husk ash as a partial cement replacement up to $30 \%$ substitution; their findings found each mix satisfied the C20/25 strength class at 91 days thus proving the potential pozzolanic qualities of RHA. Over 2 million tonnes of rice are produced every year all over the world, with Asia being the largest producer as is shown in Table I [9]. Rice husk, the outer shell that covers the rice kernel, is a product of threshed paddy to separate rice grain and the husk; over 600 million tonnes of paddy were produced in the year 2008 [9]. Paddy is of very low nutrition to even be suitable for animal feed, but of all plant residues, it contains the highest amount of silica. RHA is obtained from either controlled or uncontrolled incineration of rice husks [9].

Table 1. Rice Producing Countries in the World (cultivated area) [9].

\begin{tabular}{|c|c|c|}
\hline Rank & Country & $\begin{array}{c}\text { Rice produced } \\
\text { (millions of hectares) }\end{array}$ \\
\hline 1 & India & 43.2 \\
\hline 2 & China & 30.4 \\
\hline 3 & Indonesia & 12.2 \\
\hline 4 & Bangladesh & 12.0 \\
\hline 5 & Thailand & 9.7 \\
\hline 6 & Vietnam & 7.7 \\
\hline 7 & Burma & 6.8 \\
\hline 8 & Philippines & 4.5 \\
\hline 9 & Cambodia & 2.9 \\
\hline 10 & Pakistan & 2.9 \\
\hline
\end{tabular}

\section{Research significance}

Some work has been carried out on the performance of RHA mortar in sulfate solutions. However, no work was found on the durability performance of RHA-replaced concrete. The work reported in this paper is a review of previous work by the authors investigating the mechanical properties and durability (sulfate resistance) of RHA concrete.

\section{Experimental}

The rice husk ash was sourced from the Indian subcontinent; chemical analysis was undertaken using XRD method. The cement used was type CEM $152.5 \mathrm{~N}$. Using a mix proportion of 1:2:3, Cubes used were $100 \mathrm{~mm} \times 100 \mathrm{~mm} \times 100 \mathrm{~mm}$ in line with dimensional guidelines of BS EN 12390 [19,20]. The mix used was strength class $\mathrm{C} 25 / 30$. Cement was substituted with PCRs by weight in percentages of $0,5,7.5,10,15,20$, 25 and 30 . The $0 \%$ replacement was used as the control specimen. A water cement ratio (WCR) of 0.5 was used for all mixes. A total of three cubes were cast for each testing age and the average compressive strength was used. The cubes were left in the molds for 24 hours, before being stripped, marked and submerged in a water tank at temperatures of $200 \pm 2$ until their testing age. Compressive tests were performed to BSI guidelines [19-21] at 7, 28, 56 and 91 days.

Sulfate tests were carried out as specified in ASTM 1012 [22]. The cubes, which were used to test for strength deterioration were made using 7.5\% RHA replacement by the weight of cement, whereas the bars for expansion were made using 7.5\% RHA replacement by the volume of cement.

The specimens were demolded after having been placed in an oven for $23 \frac{1}{2}$ hours at $35^{\circ} \mathrm{C}$. Compressive tests were then carried out on two cubes to ensure that the concrete had achieved strengths of not less than 20 $\mathrm{N} / \mathrm{mm}^{2} \pm 1.0 \mathrm{~N} / \mathrm{mm}^{2}$. Sulfate solutions were prepared by mixing water with $5 \% \mathrm{Na}_{2} \mathrm{SO}_{4}, 5 \% \mathrm{MgSO}_{4}$ and mixed $2.5 \% \mathrm{Na}_{2} \mathrm{SO}_{4}+2.5 \% \mathrm{MgSO}_{4}$. The lengths of the bars were taken after which both the bars and cubes were fully immersed in the solutions. A pH of between seven and eight was maintained on the solutions throughout the period of immersion.

Length measurement was by use of a veneer calipers at weeks 1, 2, 3, 4, and 8, and at months 4, 8, and 9 conforming to [12]. Test results were an average of three specimens conforming to ASTM C1012/C1012M-15 [22].

Tests for elongation were performed on specimens that had achieved the highest compressive strength from Table 3 above, which was at the $7.5 \%$ replacement, and the $30 \%$ replacement by the volume of cement. This choice of specimens was informed by [8] and [4]'s assumption that sulfate resistance may be governed by the compressive strength more than it may depend on the amount of SCMs used to improve the chemistry of concrete.

Length change was calculated by using equation (1), which conformed to [12].

$$
\Delta L=\frac{L x-L i}{L g} \times 100
$$

Where:

$\Delta_{\mathrm{L}}=$ Percentage change in length at measuring age, 
$\mathrm{L}_{\mathrm{x}}=$ Reading of specimen at measuring age,

$\mathrm{L}_{\mathrm{i}}=$ Reading of specimen on immersion,

$\mathrm{L}_{\mathrm{g}}=160$ (nominal length between the innermost ends of the moulds used).

Observations for surface deterioration were done at the end of the 270 days of immersion.

Strength Deterioration Factors (SDFs) were used to asses strength deterioration and were calculated by using equation (2) after [13].

$$
S D F=\frac{f_{C w}-f_{C s t}}{f_{C w} t} X 100
$$

Where $f_{\mathrm{cw}}$, is the compressive strength of cube specimens that were immersed in water and $f_{c s}$ is the compressive strength of cubes immersed in sulfate solutions.

\section{Results and Discussions}

\subsection{Chemical composition}

Table I shows the chemical composition of cement and RHA. As levels of $\mathrm{Fe}_{2} \mathrm{O}_{3}$ are low, and those of $\mathrm{SiO}_{2}$ are high, it may be concluded that RHA could have a high resistance to sulfate attack, since also the ratio of $\mathrm{SO}_{3}$ to $\mathrm{Al}_{2} \mathrm{O}_{3}$, which was also reported by [2] to enhance sulfate attack when high was also low.

Table 2. Chemical composition of RHA

\begin{tabular}{|c|c|c|}
\hline \multirow{2}{*}{ Chemical } & \multicolumn{2}{|c|}{$\begin{array}{c}\text { Percentage } \\
\text { Composition }\end{array}$} \\
\cline { 2 - 3 } & Cement & RHA \\
\hline Silicon dioxide $\left(\mathrm{SiO}_{2}\right)$ & 21.9 & 87.8 \\
\hline Aluminium oxide $\left(\mathrm{Al}_{2} \mathrm{O}_{3}\right)$ & 4.0 & 0.4 \\
\hline Iron oxide $\left(\mathrm{Fe}_{2} \mathrm{O}_{3}\right)$ & 0.2 & 0.3 \\
\hline Calcium oxide $(\mathrm{CaO})$ & 66.5 & 0.7 \\
\hline Magnesium oxide $(\mathrm{MgO})$ & 1.4 & 0.6 \\
\hline Sodium oxide $\left(\mathrm{Na}_{2} \mathrm{O}\right)$ & 0.1 & 0.5 \\
\hline Potassium oxide $\left(\mathrm{K}_{2} \mathrm{O}\right)$ & 0.6 & 2.2 \\
\hline Loss on ignition $(\mathrm{LOI})$ & - & 2.2 \\
\hline Sulphur trioxide $\left(\mathrm{SO}_{3}\right)$ & 2.6 & 0.1 \\
\hline
\end{tabular}

\subsection{Compressive Strength}

Table 3 and Fig. 1 show the mean compressive strengths. The characteristic compressive strengths obtained were among those that are listed by Eurocode 2 [10] as being suitable for structural applications and durable.

\subsection{Permeability \& Sulfate Resistance}

The permeability of RHA replaced specimens is shown in Table 4. From the results, a conclusion from the assumptions of [4], and [8] that compressive strength is directly proportional to durability could be made, as lower permeability was reported at highest compressive strength as opposed to at the highest replacement; this postulation, however, has been questioned by some investigators thus due caution needs to be applied if directly correlating strength to durability.

Table 3. Mean compressive strengths of RHA-replaced specimens over 91 days of curing $\left(\mathrm{N} / \mathrm{mm}^{2}\right)$

\begin{tabular}{|r|r|r|r|r|r|r|r|r|}
\hline \multicolumn{1}{|c|}{ Age } & \multirow{2}{*}{$0 \%$} & $5 \%$ & $7.50 \%$ & $10 \%$ & $15 \%$ & $20 \%$ & $25 \%$ & $30 \%$ \\
\cline { 1 - 8 } (days) & & & & & & & & \\
\hline 7 & 56.2 & 49.0 & 47.4 & 43.1 & 40.1 & 37.8 & 37.1 & 31.2 \\
\hline 28 & 61.6 & 56.0 & 59.1 & 54.0 & 48.4 & 46.9 & 38.6 & 40.1 \\
\hline 56 & 67.6 & 60.1 & 61.5 & 57.1 & 54.9 & 53.5 & 51.9 & 43.9 \\
\hline 91 & 71.3 & 60 & 68.3 & 62.7 & 59.6 & 57.7 & 54.8 & 47.5 \\
\hline
\end{tabular}

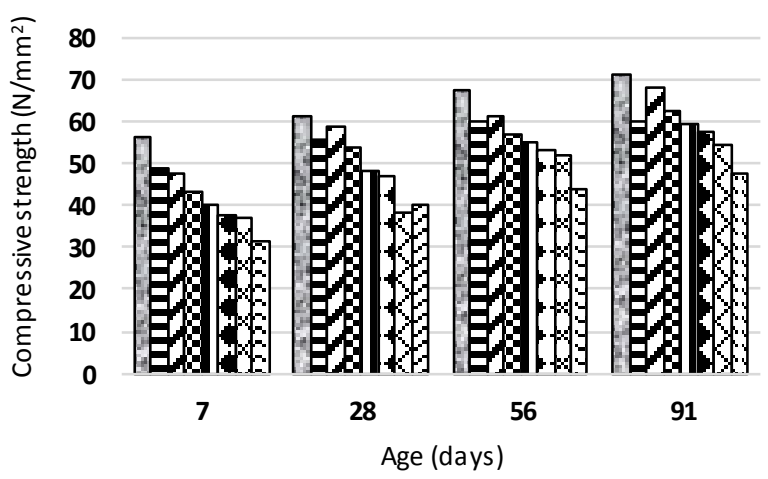
$\square 0 \% \quad \boxminus 5 \%$
D 7.50\% $10 \%$
D $15 \%$
- $20 \%$
口 $25 \% \quad$ 回 $30 \%$

Fig.1. Compressive strengths of RHA-replaced specimens over 91 days of curing $(\mathrm{N} / \mathrm{mm} 2)$.

Table 4. Coefficient of water absorption of RHA replaced specimens [Cw.s $(\mathrm{g} / \mathrm{m} 2 . \mathrm{s})]$.

\begin{tabular}{|l|l|l|l|}
\hline $\begin{array}{l}\text { Highest } \\
\text { compressive } \\
\text { strength }\end{array}$ & $\begin{array}{l}\text { Coefficient } \\
\text { of water } \\
\text { absorption } \\
{[\mathrm{C} \text { w,s }} \\
(\mathrm{g} / \mathrm{m} 2 . \mathrm{s})]\end{array}$ & $\begin{array}{l}30 \% \\
\text { replacement }\end{array}$ & $\begin{array}{l}\text { Coefficient } \\
\text { of water } \\
\text { absorption } \\
{[\mathrm{C} \text { w,s }} \\
(\mathrm{g} / \mathrm{m} 2 . \mathrm{s})]\end{array}$ \\
\hline $\begin{array}{l}\text { Control }(0 \% \\
\text { RHA })\end{array}$ & 0.5767 & Control & 0.5767 \\
\hline $7.5 \%$ RHA & 0.5075 & $30 \%$ RHA & 0.7583 \\
\hline
\end{tabular}

\subsubsection{Expansion}

Table 5 and Fig. 2 show the expansion of RHA specimens in $\mathrm{Na}_{2} \mathrm{SO}_{4}, \mathrm{MgSO}_{4}$ and mixed $\mathrm{Na}_{2} \mathrm{SO}_{4}$ and $\mathrm{MgSO}_{4}$ solutions at the highest compressive strength (the optimum mix $7.5 \%$ RHA). 
Table 5. Percentage expansion of RHA specimens at highest compressive strength $(\mathrm{mm})$

\begin{tabular}{|l|r|r|r|}
\hline Specimens & $\mathrm{Na}_{2} \mathrm{SO}_{4}$ & $\mathrm{MgSO}_{4}$ & $\begin{array}{l}\mathrm{Na}_{2} \mathrm{SO}_{4} \\
\text { and } \\
\mathrm{MgSO}_{4}\end{array}$ \\
\hline $\begin{array}{l}\text { Control }(0 \% \\
\text { RHA })\end{array}$ & 0.0937 & 0.0219 & 0.0750 \\
\hline $7.5 \%$ RHA & 0.7130 & 0.0130 & 1.4190 \\
\hline
\end{tabular}

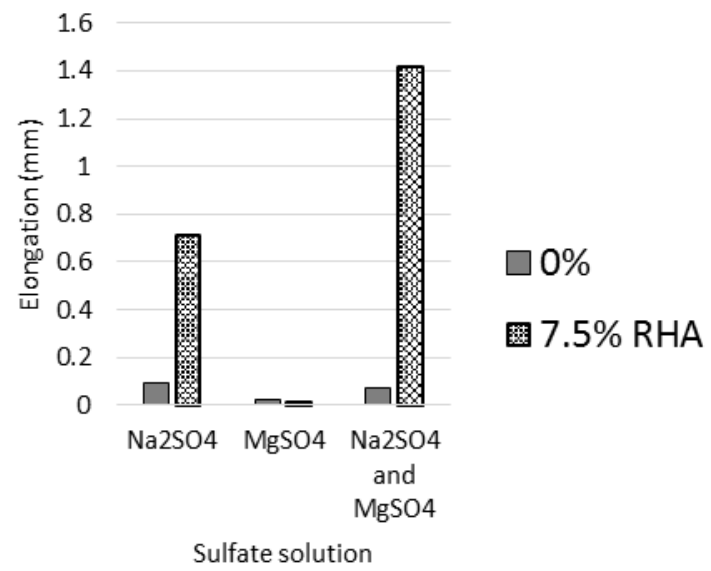

Fig. 2. Percentage expansion of RHA specimens at highest compressive strength (mm)

From the findings, the performance of the RHA specimens was below that of the 0\% RHA specimens (control) in the $\mathrm{Na}_{2} \mathrm{SO}_{4}$ and mixed $\mathrm{Na}_{2} \mathrm{SO}_{4}$ and $\mathrm{MgSO}_{4}$ solutions, whereas in the $\mathrm{MgSO}_{4}$ solution, their performance was above that of the control specimens.

These findings spell that at highest compressive strength, RHA could be used with an advantage over $100 \%$ concrete in $\mathrm{MgSO}_{4}$ environments. This may not however necessarily signify high durability in $\mathrm{MgSO}_{4}$ environment since as discussed earlier, deterioration in $\mathrm{MgSO}_{4}$ environments is evaluated through the loss of strength [2-8]. Moon, et al. [13] attributed the slight increase in length in the $\mathrm{MgSO}_{4}$ solution to the formation of brucite, even though [14] reported higher expansions on Silica Fume (SF) replaced specimens immersed in the $\mathrm{MgSO}_{4}$ solution.

Consistent with [13] the RHA specimen's performance in the mixed sulfate solution was poor, a factor which the authors attributed to the predominance of the more aggressive $\mathrm{MgSO}_{4}$ attack.

Table 6 and Fig. 3 show expansion of RHA specimens in $\mathrm{Na}_{2} \mathrm{SO}_{4}, \mathrm{MgSO}_{4}$ and mixed $\mathrm{Na}_{2} \mathrm{SO}_{4}$ and $\mathrm{MgSO}_{4}$ solutions at the $30 \%$ replacement.

Table 6. Percentage expansion of RHA specimens at $30 \%$ replacement (mm)

\begin{tabular}{|l|r|r|r|}
\hline Specimens & $\mathrm{Na}_{2} \mathrm{SO}_{4}$ & $\mathrm{MgSO}_{4}$ & $\begin{array}{l}\mathrm{Na}_{2} \mathrm{SO}_{4} \\
\text { and } \\
\mathrm{MgSO}\end{array}$ \\
\hline Control & 0.4850 & 0.1875 & 0.3500 \\
\hline $30 \%$ RHA & -0.0833 & 0.1833 & 0.4375 \\
\hline
\end{tabular}

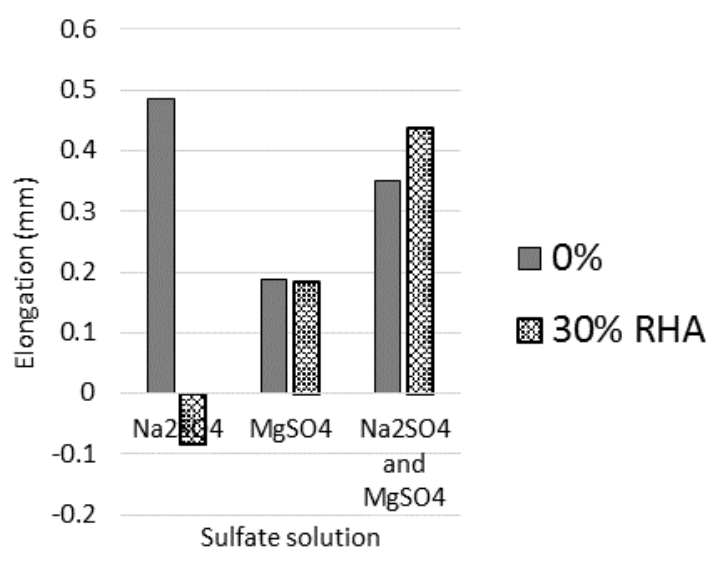

Fig. 3. Percentage expansion of RHA specimens at $30 \%$ replacement $(\mathrm{mm})$

From the findings, RHA showed a high performance in the $\mathrm{Na}_{2} \mathrm{SO}_{4}$ solution and a better performance than the control in the $\mathrm{MgSO}_{4}$ solution, even though its performance in the mixed sulfate solution was below that of the control. These findings are consistent with [15] and [13], who also reported a better performance than the control on RHA in reducing gypsum and ettringite.

As discussed earlier, SCMs aid in resisting sulfate attack as they refine pores, dilute $\mathrm{C}_{3} \mathrm{~A}$ and remove $\mathrm{Ca}(\mathrm{OH})_{2}$ by converting it into C-S-H, thereby reducing the quantities of gypsum formed [2].

The results are not however consistent with findings in the literature that $\mathrm{MgSO}_{4}$ attack can only manifest in the loss of strength and not in expansion [2], since as stated earlier, [14] also reported expansion on bars that were immersed in the $\mathrm{MgSO}_{4}$ solution.

Even though [4] reported that low permeability is important as it inhibits the diffusion of harmful substances into the concrete matric, the findings of this study call into question this assumption since from Table 4 , [11] reported a lower coefficient of water absorption at the $7.5 \%$ replacement than at the $30 \%$ replacement, and yet the results show a lower expansion at the $30 \%$ replacement than at the $7.5 \%$ replacement in the $\mathrm{Na}_{2} \mathrm{SO}_{4}$ and mixed sulfate solutions.

The results are also not consistent with [2]'s assumptions that the filler effect of unreacted particles improves permeability. Adesanya \& Raheem [1] however attributed the high permeability at high replacements to low levels of $\mathrm{Ca}(\mathrm{OH})_{2}$ available to react with excess SCMs for the formation of the less permeable C-S-H.

\subsubsection{Strength deterioration factors (SDFs)}

As discussed in the methods section, the loss of strength was assessed using Strength Deterioration Factors (SDFs) after [13]. Table 7 shows the SDFs of the RHA specimens that were immersed in $\mathrm{Na}_{2} \mathrm{SO}_{4}, \mathrm{MgSO}_{4}$ and mixed $\mathrm{Na}_{2} \mathrm{SO}_{4}$, and $\mathrm{MgSO}_{4}$ solutions. The RHA specimens showed lower SDFs than the control specimens in the $\mathrm{Na}_{2} \mathrm{SO}_{4}$ and mixed sulfate solutions. 
The findings confirmed findings in the literature that $\mathrm{MgSO}_{4}$ attacks C-S-H in SCMs to form the noncementitious $\mathrm{M}-\mathrm{S}-\mathrm{H}$, and hence the higher SDFs recorded for the RHA specimens than those of the control specimens in the $\mathrm{MgSO}_{4}$ solution [2].

These results were also consistent with the findings of Kamau et al [16] and [17] who reported lower SDFs than those of the control on maize cob ash specimens in the $\mathrm{Na}_{2} \mathrm{SO}_{4}$ and mixed sulfate solutions, but higher than those of the control in the $\mathrm{MgSO}_{4}$ solution.

The low SDFs of the RHA specimens in the $\mathrm{Na}_{2} \mathrm{SO}_{4}$ and mixed sulfate solutions spell the possibility of using RHA with an advantage over $100 \%$ cement to improve the performance of concrete in these environments. Although there are contradictory notions regarding correlating strength to durability, the RHA samples clearly have greater strength deterioration resistance in comparison to $100 \%$ cement concrete.

Table 7. Strength Deterioration Factors (SDFs) of RHA specimens at 270 days (\%)

\begin{tabular}{|l|l|l|}
\hline & Control & $7.5 \%$ RHA \\
\hline $5 \% \mathrm{Na}_{2} \mathrm{SO}_{4}$ & 8.6 & 2.6 \\
\hline $5 \% \mathrm{MgSO}_{4}$ & 17.7 & 27.5 \\
\hline $2.5 \% \mathrm{Na}_{2} \mathrm{SO}_{4}+2.5 \% \mathrm{MgSO}_{4}$ & 26.9 & 15.9 \\
\hline
\end{tabular}

\subsubsection{Surface deterioration}

Table 8 shows surface deterioration observed on the RHA specimens that were immersed in $\mathrm{Na}_{2} \mathrm{SO}_{4}, \mathrm{MgSO}_{4}$ and mixed $\mathrm{Na}_{2} \mathrm{SO}_{4}$ and $\mathrm{MgSO}_{4}$ solutions. The method used by [18] to assess strength deterioration was employed. RHA was observed to improve the surface deterioration of specimens in all the three sulfate solutions over the control specimens.

The findings were not consistent with [13] who reported higher surface deterioration on the control specimens than on the SF specimens in the $\mathrm{Na}_{2} \mathrm{SO}_{4}$ solution,

Table 8. Surface deterioration of RHA specimens in sulfate solutions after [18]

\begin{tabular}{|l|l|l|}
\hline & Control & $7.5 \%$ RHA \\
\hline $5 \% \mathrm{Na}_{2} \mathrm{SO}_{4}$ & 0 & 0 \\
\hline $5 \% \mathrm{MgSO}_{4}$ & 0 & 0 \\
\hline $2.5 \% \mathrm{Na}_{2} \mathrm{SO}_{4}+$ & & \\
$2.5 \% \mathrm{MgSO}_{4}$ & 2 & 1 \\
\hline
\end{tabular}

Key: Deterioration levels. 0, no damage; 1 , minimum visible cracks; 2 , mass loss and some disintegration; 3, extensive spalling and softening; 4, wider cracks and extensive spalling; 5 , Complete disintegration

\section{Conclusion}

This work investigated the performance of RHA replaced concrete in sodium sulfate $\left(\mathrm{Na}_{2} \mathrm{SO}_{4}\right)$, magnesium sulfate $\left(\mathrm{MgSO}_{4}\right)$ and mixed $\mathrm{Na}_{2} \mathrm{SO}_{4}$ and
$\mathrm{MgSO}_{4}$ environments. From the findings, the following conclusions were drawn: -

1. At the highest compressive strength (7.5\% replacement) in expansion, RHA could be used with an advantage over $100 \%$ cement in $\mathrm{MgSO}_{4}$ environments

2. At the $30 \%$ replacement, RHA could be used with an advantage over $100 \%$ cement in $\mathrm{Na}_{2} \mathrm{SO}_{4}$ and $\mathrm{MgSO}_{4}$ environments

3. Strength deterioration results indicate that RHA could be used with an advantage over $100 \%$ cement in $\mathrm{Na}_{2} \mathrm{SO}_{4}$ and $\mathrm{MgSO}_{4}$ environments

4. Surface deterioration results show that RHA could be used with an advantage over $100 \%$ cement in $\mathrm{Na}_{2} \mathrm{SO}_{4}, \mathrm{MgSO}_{4}$ and mixed sulfate environments.

The authors wish to thank the learning officers Kevin Smith and Andy Brannan for their assistance with this research.

\section{References}

1. D. Adesanya and A. Raheem, "A study of the permeability and acid attack of corn cob ash blended cements," Construction and Building Materials, vol. 24, pp. 403-409, 2010.

2. J. D. Bapat, Mineral admixtures in cement and concrete: CRC Press, 2012.

3. M. Shetty, Concrete technology: theory and practice: S. Chand. ISBN 8121900034, 2005.

4. A. M. Neville and J. J. Brooks, Concrete technology. Longman Scientific and Technical. ISBN 0-582-988594, 1987.

5. T. C. Holland, Silica fume user's manual: Federal Highway Administration, Silica Fume Association (SFA) Washington, 2005.

6. P. Mehta, "Sulfate attack on concrete--a critical review," Mater. Sci. Concr., IIIpp., vol. 105, 1992.

7. I. Richardson, "The nature of the hydration products in hardened cement pastes," Cement and Concrete Composites, vol. 22, pp. 97-113, 2000.

8. C. Arya, Design of structural elements: concrete, steelwork, masonry and timber designs to British standards and Eurocodes. Spon Press, LONDON AND NEW YORK: Taylor \& Francis, 2009.

9. J. Kamau, A. Ahmed, F. Hyndman, P. Hirst, and J. Kangwa, "Influence of Rice Husk Ash Density on the Workability and Strength of Structural Concrete," EJERS, European Journal of Engineering Research and Science, vol. Vol. 2, , p. 36 to 43, March 20172017.

10. British Standards Institution, "BS EN 1992-11:2000. Eurocode 2: Design of Concrete Structures, Part 1-1: General Rules and Rules for Buildings. BSI, London, UK," ed, 2004.

11. J. Kamau, A. Ahmed, P. Hirst, and J. Kangwa, "Permeability of corncob ash, anthill soil and rice husk ash replaced concrete," International Journal of 
Science, Environment and Technology, vol. 6, pp. 1299-1308, 2017.

12. American Society for Testing and Materials, "ASTM C1012/C1012M-15. Standard Test Method for Length Change of Hydraulic-Cement Mortars Exposed to a Sulfate Solution1. 100 Barr Harbor Drive, PO Box C700, West Conshohocken, PA 19428-2959. United States," ed, 2015.

13. H.-Y. Moon, S.-T. Lee, and S.-S. Kim, "Sulphate resistance of silica fume blended mortars exposed to various sulphate solutions," Canadian Journal of Civil Engineering, vol. 30, pp. 625-636, 2003.

14. Y.-S. Park, J.-K. Suh, J.-H. Lee, and Y.-S. Shin, "Strength deterioration of high strength concrete in sulfate environment," Cement and concrete research, vol. 29, pp. 1397-1402, 1999.

15. P. Chindaprasirt, P. Kanchanda, A. Sathonsaowaphak, and H. Cao, "Sulfate resistance of blended cements containing fly ash and rice husk ash," Construction and Building Materials, vol. 21, pp. 1356-1361, 2007.

16. J. Kamau, A. Ahmed, P. Hirst, and J. Kangwa, "Suitability of Corncob Ash as a Supplementary Cementitious Material," International Journal of Materials Science and Engineering, vol. 4, pp. 215228, 2016.
17. J. Kamau, A. Ahmed, P. Hirst, and J. Kangwa, "Performance of Anthill Soil Replaced Concrete in Sulfate Solutions," European Journal of Engineering Research and Science, vol. 2, pp. 50-55, 2017.

18. O. S. B. Al-Amoudi, "Studies on soil-foundation interaction in the sabkha environment of eastern province of Saudi Arabia," Civil Engineering, 1992.

19. BSI, "BS EN 12390-1:2012. Testing hardened concrete. Part 1: Shape, dimensions and other requirements for specimens and moulds. British Standards Institution (BSI), London, UK," 2012.

20. BSI, "BS EN 12390-2:2009. Making and curing specimens for strength tests. British Standards Institution (BSI), London, UK," 2009.

21. BSI, "BS EN 12390-4:2000. Testing hardened concrete. Compressive strength. Specification for testing machines. British Standards Institution (BSI), London, UK," 2000.

22. ASTM, "C1012/C1012M-15. Standard Test Method for Length Change of Hydraulic-Cement Mortars Exposed to a Sulfate Solution1," American Society for Testing and Materials, 2015. 